\title{
EKSPLOITASI FAUNA DI SITUS LIANGAN, TEMANGGUNG: KAJIAN ARKEOZOOLOGI
}

\author{
FAUNAL EXPLOITATION AT LIANGAN SITE, \\ TEMANGGUNG: \\ AN ARCHAEOZOOLOGICAL STUDY
}

\author{
Sofwan Noerwidi \\ Balai Arkeologi D.I. Yogyakarta \\ noerwidi@arkeologijawa.com
}

\begin{abstract}
Liangan is a settlement site of Old Mataram in periodic of VI-X AD. Various aspects of ancient Javanese culture has been recovered from Liangan site, but has never been examined the relationship between human and fauna in the past. The study aims to determine the pattern of faunal exploitation through archaeozoological approach, which use ecofact (faunal bones and teeth) that were found in the 2016 excavation campaign. This study conducts qualitative analysis of morphological character of the bones and teeth. Archaeozoological study is covering biological aspects of fauna, and cultural aspects related to human activity. These aspects are including anatomical preservation condition, taphonomy (deposition process), taxonomy (species), age estimation and faunal diet pattern. In the result, mainly bones and teeth are identified as buffalo (Bubalus sp). Taphonomical preservation condition of buffalo bone indicating faunal exploitation for human consumption. The climatic condition of Sindoro highland which is not buffalo's natural habitat indicates an intensive human intervention as domestication. This study shows that buffalo on Liangan site eat more leaves as browser which probably supplied by human.
\end{abstract}

Keyword : Archaeozoology, Liangan, Old Mataram, Domestication, Faunal Exploitation, Buffalo.

\begin{abstract}
ABSTRAK
Liangan adalah sebuah situs permukiman masa Mataram Kuna yang dihuni pada sekitar abad VI-X Masehi. Berbagai aspek budaya masyarakat Jawa Kuna telah berhasil diungkap dari situs Liangan, namun belum ada yang mengkaji relasi antara manusia dan fauna di situs ini. Penelitian ini bertujuan untuk mengetahui pola eksploitasi fauna pada masa lampau melalui pendekatan arkeozoologi. Penelitian ini menggunakan pendekatan arkeozoologi, dengan data ekofak berupa tulang dan gigi fauna yang ditemukan pada penelitian 2016. Analisis dilakukan secara kualitatif terhadap karakter morfologi (aspek bentuk) yang masih terpreservasi pada tulang dan gigi fauna. Studi arkeozoologi dalam penelitian ini mencakup beberapa aspek biologis fauna, dan aspek kultural yang berhubungan dengan pola tingkah laku manusia. Aspek-aspek tersebut meliputi kondisi preservasi anatomi, tafonomi (proses deposisi), taksonomi (jenis fauna), estimasi usia dan pola diet fauna. Hasilnya, diketahui bahwa hampir keseluruhan tulang dan gigi fauna di situs Liangan berasal dari jenis Kerbau (Bubalus sp). Kondisi preservasi dan tafonomi tulang kerbau mengindikasikan adanya eksploitasi fauna untuk dikonsumsi. Kondisi lingkungan dataran tinggi Sindoro yang tidak banyak menyediakan padang rumput sebagai habitat alami Kerbau, mendorong campur tangan intensif manusia dalam bentuk domestikasi. Berdasarkan studi gigigeligi diketahui pula bahwa Kerbau di situs Liangan lebih banyak mengkonsumsi daun (browser) yang asalnya kemungkinan besar disediakan oleh manusia.
\end{abstract}

Kata Kunci : Arkeozoologi, Liangan, Mataram Kuna, Domestikasi, Eksploitasi Fauna, Kerbau.

Tanggal Masuk : 12 Februari 2017

Tanggal Diterima : 16 Februari 2017 


\section{PENDAHULUAN}

Situs Liangan secara berada di Dusun Liangan, Desa Purbosari, Kecamatan Ngadirejo, Kabupaten Temanggung, Jawa Tengah. Secara astronomis, lokasi yang berada di antara permukiman dan lahan pertanian tersebut terletak pada $7^{\circ}$ 15'01.8" LS dan $110^{\circ} 01^{\prime}$ '44.8" BT berada di lereng utara Gunung Sindoro, dengan ketinggian dari permukaan air laut sekitar 11001.200 meter (Tim Penelitian, 2016: 1).
D.I. Yogyakarta dengan sebuah penelitian yang intensif sejak 2010 hingga 2014 dalam kerangka program Penelitian Jangka Menengah I yang dipimpin oleh Drs. Sugeng Riyanto, M.Hum. Sasaran umum program ini meliputi keragaman data, kerangka keruangan dengan luasan situs, kronologi dalam kerangka historis (kesejarahan), geologi dan geomorfologi, aspek religi, serta dinamika hunian (Tim Penelitian, 2016: 2).

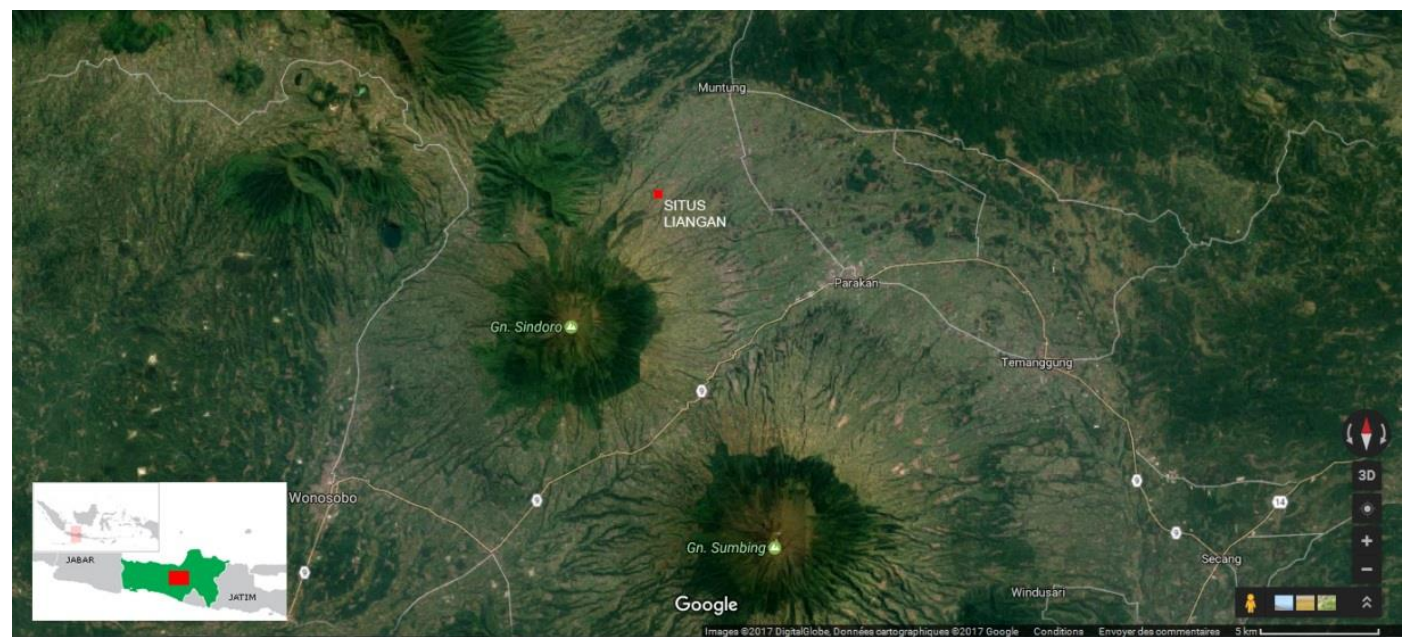

Gambar 1. Peta Keletakan Situs Liyangan (Sumber: Google Earth, dengan modifikasi)

Penelitian situs Liangan awalnya merupakan tanggapan atas laporan warga pada tahun 2009 mengenai penemuan lempeng batu dengan tatanan konstruksi mirip tembok di rumah Bapak Sucipto, salah seorang warga. Batu tersebut ditemukan di antara dapur dan kandang kambing. Setelah penemuan di rumah warga tersebut, penambang di Liangan menemukan benda-benda arkeologis di situs yang lainnya. Beberapa yang ditemukan antara lain: talud batu, batu candi, dan fragmen artefak (Rangkuti dan Tjahjono, 2000; Riyanto, 2014b: 33-34).

Penemuan ini kemudian ditindaklanjuti oleh Balai Arkeologi
Hasil dari penelitian periode 2010-2014 tersebut telah dirangkum dalam sebuah monografi berjudul Liangan: Mozaik Peradaban Mataram Kuno Di Lereng Sindoro (2014). Monografi ini merupakan kumpulan kajian mengenai Situs Liangan yang dilakukan oleh para peneliti. Terdapat 11 tulisan yang masing-masing memberikan kontribusi hasil penemuannya berdasarkan pada sudut pandang keahlian yang berbeda.

Secara umum, kondisi fisik situs permukiman Mataram Kuna ini tertutup material lahar setebal 6-10 meter hasil aktivitas vulkanisme Gunung Sindoro (Nurnusanto, 2014: 117-122). Berdasarkan hasil 
Penelitian Jangka Menengah I telah diketahui empat kluster area: Hunian, Peribadatan Hindu, Pertanian, dan Perbengkelan. Pada awalnya, situs Liangan diduga merupakan kompleks bangunan suci (candi), tetapi kemudian setelah dilakukan penelitian yang lebih intensif diketahui bahwa situs tersebut merupakan kompleks permukiman masa Jawa Kuna (Riyanto, 2014a: 7).

Berdasarkan kajian sumber sejarah melalui prasasti. Rukam berbentuk lempeng tembaga berangka tahun $907 \mathrm{M}$ dapat diketahui adanya nama desa wanua $i$ rukam adalah desa yang hilang karena terjadinya letusan gunung berapi (Nastiti dkk, 1982:6). Namun interpretasi ini telah dikoreksi oleh Mochtar (2014) karena nama wanua i rukam adalah desa yang menggantikan status sima dari desa lainnya yang hilang tertimbun material letusan gunung berapi. Catatan ini penting artinya karena memiliki makna bahwa "desa lainnya" yang digantikan status simanya oleh wanua i rukam kemungkinan adalah Liangan kuno (Riyanto, 2014a: 14).

Saat ini baru satu rangka manusia yang ditemukan di Situs Liangan. Rangka ini dimakamkan pada suatu konteks kubur sekunder yang hanya melibatkan beberapa anggota tulang utamanya saja. Berdasarkan hasil analisis bioarkeologi yang telah dilakukan dapat diketahui bahwa rangka tersebut adalah milik seorang perempuan yang berumur sekitar 18-22 tahun. Individu ini memiliki ciri populasi Mongoloid yang kuat dengan beberapa campuran karakter Australo-Melanesoid. Perempuan muda tersebut mengidap beberapa penyakit periodontal dan mengalami modifikasi gigi yang berhubungan dengan aspek estetika (Noerwidi, 2016: 96).

Temuan ekofak yang menarik dari situs Liangan adalah temuan arang gabah di area hunian. Cristina Castillo (2014) telah melakukan analisis statistik morfologis dan morfometrik sampai pada kesimpulan bahwa arang gabah dari situs Liangan merupakan bukti keberadaan jenis padi Oryza tropical japonica yang pertama ditemukan di Indonesia. Kemudian Katsunori Tanaka (2014) melalui analisis chloroplast DNA mengidentifikasi kehadiran unsur indica selain japonica pada arang gabah dari situs Liangan.Temuan ini mengindikasikan bahwa masyarakat Jawa Kuna abad VI-X M telah mengenal budidaya padi secara intensif. Selain itu juga terdapat kemungkinan adanya intrusi vegetasi padi jenis baru dari Asia daratan ke Pulau Jawa yang dibawa oleh manusia melalui jalur pelayaran perdagangan (Riyanto, 2014a:19).

Aspek budaya lainnya yang telah dibahas adalah mengenai banyaknya temuan keramik dinasti Tang abad IX M. Temuan ini mengindikasikan adanya hubungan pelayaran dan perdagangan yang intensif antara Cina dengan kepulauan Nusantara. Hasil analisis Yusmaeni Eriawati (2014) dapat diketahui beberapa jenis wadah dengan berbagai variasi, tipe, serta ukuran, yaitu: tempayan, guci, pasu, mangkuk, teko, dan botol. Berdasarkan fungsinya, ada kemungkinan bahwa temuan tersebut tidak berfungsi praktis untuk keperluan sehari-hari. $\mathrm{Hal}$ ini dibuktikan dengan temuan barangbarang yang cukup langka dalam segi kuantitas dan kualitas, maka barang-barang tersebut sangatlah 
mungkin berfungsi sakral (Eriawati, 2014: 256).

Berdasarkan pada hasil penelitian yang telah dihasilkan tersebut, masih belum banyak diketahui pola tingkah laku manusia pada masa Mataram Kuna abad VI$X M$ yang berhubungan dengan lingkungan alam sekitarnya khususnya fauna atau hewan. Oleh karena itu, maka secara khusus, penelitian ini bertujuan untuk mengetahui eksploitasi fauna pada masa Mataram Kuna sekitar abad VI-X Masehi berdasarkan pendekatan arkeozoologi.

Studi arkeozoologi adalah salah satu cabang ilmu arkeologi yang secara khusus mengkaji sisa fauna, meliputi: tulang, gigi, cangkang, keratin, bulu, protein dan DNA- yang ditemukan pada konteks arkeologis (Yohe II, 2006: 248). Kajian ini bertujuan untuk mengetahui sejarah hubungan natural dan kultural antara manusia dengan hewan, seperti misalnya domestikasi dan etnozoologi.

Studi arkeozoologi di Indonesia, khususnya fauna dari masa sejarah masih sangat jarang dilakukan. Kajian sejenis mengenai sisa fauna pada masa protosejarah antara lain pernah dilakukan oleh Awe (1987) terhadap sisa fauna vertebrata dari situs Plawangan III. Kemudian, identifikasi fauna pada masa Jawa Kuna pernah dilakukan oleh Siswanto (1999: 1-41) berdasarkan relief flora dan fauna tinggalan masa Majapahit. Oleh sebab masih sedikitnya studi arkeozoologi tersebut, maka kajian ini berusaha memberikan perspektif mengenai hubungan antara manusia dengan hewan pada masa Mataram Kuna.

Secara khusus, masalah yang diangkat dalam tulisan ini adalah:1) Bagaimana aspek biologis fauna di situs Liangan berdasarkan sisa tulang dan gigi yang ditemukan? 2) Bagaimana hubungan sisa fauna tersebut dengan aspek kultural manusia? Permasalahan ini akan dijawab dengan pendekatan arkeozoologi.

\section{METODE}

Penelitian arkeozoologi ini bersifat deskriptif komparatif dengan cara mendeskripsikan data secara sistematis untuk kemudian dilakukan analisis perbandingan dengan data dari penelitian serupa yang pernah dilakukan (Gaudzinski-Windheuser dan Kindler, 2012). Data utama yang digunakan dalam penelitian ini merupakan ekofak berupa temuan tulang dan gigi hewan yang ditemukan di situs Liangan, Temanggung pada ekskavasi tahun 2016.

Identifikasi temuan tulang fauna dilakukan secara kualitatif terhadap karakter morfologi (aspek bentuk) yang masih terpreservasi pada temuan yang bersangkutan. Analisis arkeozoologi dilakukan dengan menggunakan bantuan beberapa referensi bibliografis mengenai arkeozoologi, seperti rujukan dari Barone (1976), Pales dan Gracia (1981), Schmidt (1972), serta Hilson (2005).

Studi arkeozoologi dalam tulisan ini akan mencakup beberapa aspek biologis fauna, maupun yang berhubungan dengan aspek kultural manusia. Aspek-aspek tersebut antara lain adalah kondisi preservasi, tafonomi (proses deposisi), taksonomi (jenis fauna), usia fauna dan diet. 


\section{HASIL PENELITIAN}

Tulang fauna dari situs Liangan, ditemukan dari beberapa lokasi baik di permukaan tanah melalui survei, maupun terpendam dalam tanah yang terungkap melalui ekskavasi. Deskripsi temuan tulang fauna pada bagian ini merupakan hasil identifikasi pada masingmasing spesimen yang ditemukan. Pengelompokan temuan tidak akan dilakukan berdasarkan kotak ekskavasi, namun dikelompokkan berdasarkan pada blok ekskavasi yang dipertimbangkan memiliki konteks secara arkeologis. Berikut ini adalah hasil rekapitulasi temuan dari tiap blok tersebut:
Temuan dari lokasi ini adalah gigigeligi dari Bovidae, serta rahang Canidae. Berikut adalah temuan dari Blok Jalan Batu Halaman III :

Tabel 1.Temuan Fauna pada Blok Jalan Batu Halaman III

\begin{tabular}{lllll}
\hline No. & Fragmen & Anatomi & Jenis & Jml \\
\hline $\mathbf{1}$ & Corpus & Mandible & Canidae & 1 \\
2 & Gigi & Molar & Bovidae & 5 \\
& Total & & & \\
\hline $\begin{array}{l}\text { Sumber: Tim } \\
\text { modifikasi }\end{array}$ & Penelitian, & 2016 & dengan & \\
\hline
\end{tabular}

\section{LT 1501 Blok S24 B1-3}

Blok ini berada sekitar 50 meter di sebelah selatan bangunan candi. Temuan pada lokasi ini

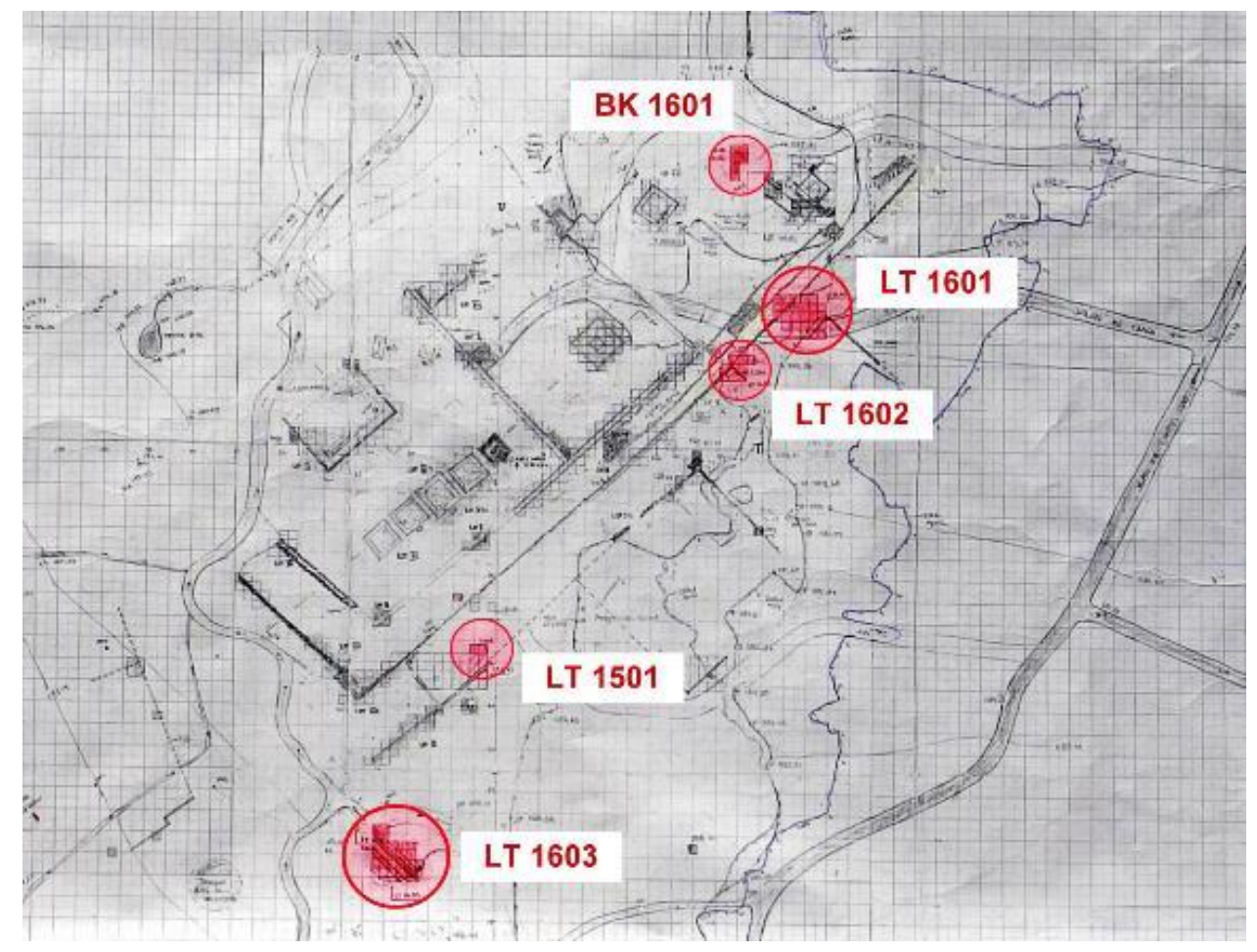

Gambar 2.Denah Ekskavasi Situs Liangan Tahun 2016. Ket: LT = Lubang Tambang, BK = Blok (Sumber: Balai Arkeologi D.I. Yogyakarta, 2016)

\section{Blok Jalan Batu Halaman III}

Seluruh Blok ini berada di sekitar jalan batu Halaman III bangunan candi. Temuan pada lokasi ini berasal dari permukaan tanah pada saat dilakukan survei. berasal dari kedalaman antara 130$145 \mathrm{~cm}$. Temuan dari lokasi ini adalah tulang pinggul dan gigi-geligi dari fauna Bovidae. Berikut ini adalah temuan dari Blok S24 B1-3: 
Tabel 2.Temuan Fauna pada LT 1501 Blok S24 B1-3

\begin{tabular}{ccccr}
\hline No. & Fragmen & Anatomi & Jenis & Jml \\
\hline 1 & & Pelvis & Bovidae & 1 \\
2 & Gigi & Premolar & Bovidae & 1 \\
3 & Gigi & Molar & Bovidae & 1 \\
& Total & & & $\mathbf{3}$ \\
\hline
\end{tabular}

Sumber: Tim Penelitian, 2016 dengan modifikasi

\section{LT 1601 Blok U15-18 T34-37}

Blok ini merupakan lokasi yang paling kaya dengan temuan tulang fauna. Lokasinya berada sekitar 30 meter di sebelah utara rerntuhan bangunan candi. Temuan pada lokasi ini berasal dari lapisan 2 dan 3. Temuan dari lokasi ini adalah tulang panjang, tulang pinggul, persendian, tulang belikat, dan gigigeligi dari fauna Bovidae. Berikut ini adalah temuan dari Blok U15-18 T34-37:

Tabel 3.Temuan Fauna pada LT 1601 Blok U15 T34-37

\begin{tabular}{rlllr}
\hline No. & Fragmen & Anatomi & Jenis & Jml \\
\hline 1 & & Astragalus & Bovidae & 1 \\
2 & & Costae & Bovidae & 1 \\
3 & & Indet & Bovidae & 5 \\
4 & & Mandible & Bovidae & 1 \\
5 & Diaphysis & Metacarpal & Bovidae & 1 \\
6 & Gigi & Molar & Bovidae & 5 \\
7 & & Pelvis & Bovidae & 2 \\
8 & & Persendian & Bovidae & 6 \\
9 & & Scapula & Bovidae & 3 \\
10 & Diaphysis & Tulang & Bovidae & 6 \\
11 & & Panjang & & \\
& & Tulang & Bovidae & 2 \\
12 & Epi. Prox & Plna & Bovidae & 1 \\
13 & Epi. Dist & Ulna & Bovidae & 1 \\
14 & Diaphysis & Tulang & Indet & 1 \\
& & Panjang & & \\
15 & Tulang & Indet & Indet & 6 \\
\hline \multirow{4}{*}{ Sumber: Tim } & Total & & & 42 \\
\hline
\end{tabular}
modifikasi

\section{LT 1603 Blok S46-48 B10-14}

Blok ini berada sekitar 90 meter di sebelah selatan reruntuhan bangunan candi, pada kontur yang lebih tinggi. Temuan pada lokasi ini berasal dari lapisan 2. Temuan dari lokasi ini adalah tulang panjang, tulang belikat, dan gigi dari fauna Bovidae. Berikut ini adalah temuan dari Blok S46-48 B10-14 :

Tabel 4.Temuan Fauna pada LT 1603 Blok S46-48 B10-14

\begin{tabular}{ccccr}
\hline No. & Fragmen & Anatomi & Jenis & Jml \\
\hline $\mathbf{1}$ & Tulang & Indet & Indet & 2 \\
$\mathbf{2}$ & Gigi & Molar & Bovidae & 1 \\
$\mathbf{3}$ & Diaphysis & $\begin{array}{c}\text { Tulang } \\
\text { Panjang }\end{array}$ & Bovidae & 2 \\
$\mathbf{4}$ & \multicolumn{1}{c}{ Scapula } & Bovidae & 1 \\
\multicolumn{5}{c}{ Total } \\
$\begin{array}{l}\text { Sumber: Tim } \\
\text { modifikasi }\end{array}$ & Penelitian, 2016 & dengan \\
\end{tabular}

\section{LT 1603 Blok S50-51 B10-13}

Blok ini berada sekitar 100 meter di sebelah selatan bangunan candi, pada kontur yang lebih tinggi. Temuan pada lokasi ini berasal dari lapisan 2 dan 3. Temuan dari lokasi ini adalah tulang panjang, tulang punggung, tulang rusuk, tulang belikat, dan gigi-geligi dari fauna Bovidae. Berikut ini adalah temuan dari Blok S50-51 B10-13:

Tabel 5.Temuan Fauna pada LT 1603 Blok S50-51 B10-13

1603 Blok S50-51 B10-13

\begin{tabular}{ccccr}
\hline No. & Fragmen & Anatomi & Jenis & Jml \\
\hline 1 & $\begin{array}{c}\text { Processus } \\
\text { Spinous }\end{array}$ & Vertebrae & Bovidae & 1 \\
2 & Gigi & Molar & Bovidae & 3 \\
3 & Diaphysis & $\begin{array}{c}\text { Tulang } \\
\text { Panjang }\end{array}$ & Bovidae & 8 \\
4 & & Costae & Bovidae & 2 \\
5 & & Scapula & Bovidae & 1 \\
6 & Tulang & Indet & Bovidae & 1 \\
& Total & & & $\mathbf{1 6}$ \\
\hline
\end{tabular}

Sumber: Tim Penelitian, 2016 dengan modifikasi 


\section{DISKUSI DAN PEMBAHASAN}

Studi arkeozoologi dalam tulisan ini mencakup beberapa aspek biologis fauna, maupun yang berhubungan dengan aspek kultural manusia. Aspek-aspek tersebut antara lain adalah kondisi preservasi, tafonomi (proses deposisi), taksonomi (jenis fauna), usia fauna dan diet. Berikut adalah hasil analisis arkeozoologi dan interpretasi temuan tulang-tulang fauna dari situs Liangan.

\section{Preservasi Anatomis}

Hal yang paling mendasar dalam studi arkeozoologi adalah mengetahui kondisi preservasi tulang fauna yang ditemukan. Mengukur persentase preservasi elemen tulang dalam konteks arkeologis, sangat penting dalam studi arkeozoologi. Pengukuran ini tidak hanya bertujuan untuk membedakan akumulasi yang disebabkan oleh faktor alami dan antropik, tetapi juga digunakan untuk mengetahui praktek eksploitasi fauna oleh manusia, transportasi fauna, kebutuhan gizi, hingga aktivitas pemilihan spesies tertentu (Marean dan Spencer 1991: 645).

Dalam suatu akumulasi yang disebabkan oleh perangkap alami, biasanya secara kuantitas tulang yang berlimpah adalah tulang bagian aksial, yang posisinya satu sama lain saling terhubung secara anatomis. Oleh karena itu, maka perlu mengamati pola akumulasi yang disebabkan baik oleh karnivora maupun manusia. Hal ini dapat diketahui berdasarkan representasi dan persentase dari indeks elemen kerangka terpreservasi. Proporsi kehadiran rangka fauna di situs arkeologi sangat tergantung pada faktor penyebab yang terlibat dalam pembentukan deposit (Lyman, 1984:
259-260). Menurut Klein dan CruzUribe (1984: 6-7), hubungan antara elemen tengkorak/non-tengkorak dengan ukuran hewan dapat digunakan untuk menentukan faktor yang menyebabkan akumulasi sisasisa fauna.

Persentase rangka terpreservasi dihitung untuk semua tulang dalam satu kerangka dan berdasarkan jenis fragmen, terutama untuk tulang panjang (diafisis, distal dan proksimal epifisis). Dalam penelitian ini digunakan persentase frekuensi MNE (Minimum Number of Elemen) pada setiap elemen anatomi. Berikut ini adalah hasil analisis terhadap sisa rangka fauna yang terpreservasi di situs Liangan:

Tabel 6.Jumlah Minimum Elemen Anatomi yang Terpreservasi

\begin{tabular}{lrr}
\hline \multicolumn{1}{c}{ ANATOMI } & JUMLAH & \multicolumn{1}{c}{$\%$} \\
\hline Mandible & 2 & 2.74 \\
Gigi-geligi & 16 & 21.92 \\
Scapula & 5 & 6.85 \\
Tulang Panjang & 22 & 30.14 \\
Vertebrae & 1 & 1.37 \\
Costae & 3 & 4.11 \\
Pelvis & 3 & 4.11 \\
Persendian & 7 & 9.59 \\
Indet & 14 & 19.18 \\
TOTAL & $\mathbf{7 3}$ & $\mathbf{1 0 0}$ \\
\hline Sumber: Tim & Penelitian, \\
modifikasi & 2016 & dengan
\end{tabular}

Berdasarkan hasil

perhitungan persentase frekuensi pada setiap elemen anatomi, maka dapat diketahui bahwa frekuensi terbesar berasal dari tulang panjang, gigi-geligi, dan tulang Indet (tidak teridentifikasi). Fragmen tulang panjang sebagai anatomi yang paling banyak ditutupi oleh jaringan otot-otot atau daging memunculkan dugaan bahwa akumulasi temuan tulang fauna di situs Liangan disebabkan oleh faktor manusia. 
Dugaan ini semakin diperkuat dengan tidak adanya beberapa anggota anatomi lainnya yang kurang disukai oleh manusia untuk dikonsumsi, seperti misalnya distal phalange (jari), maxilla (rahang atas), dan tanduk.

\section{Proses Tafonomi}

Fragmentasi tulang dapat disebabkan baik oleh proses alam atau faktor antropik, dan bahkan keduanya. Intervensi manusia pada bentuk fragmentasi tulang terkait dengan transportasi, penyembelihan, distribusi daging, memasak, pembuangan, dan juga kegunaan non subsistensi lainnya. Menurut Binford (1981) dan Lyman (1994), representasi rangka fauna di situs arkeologi dapat membantu kita untuk mengidentifikasi agen yang terlibat dalam proses deposisi (tafonomi) tulang fauna.

Blumenschine (1986) telah menunjukkan bahwa kelimpahan elemen anatomi tertentu dapat membedakan aktivitas konsumsi yang disebabkan oleh karnivora atau manusia. Selain itu, dapat juga dibedakan antara jejak aktivitas yang disebabkan oleh gigitan karnivora, maupun jejak goresan artefak yang digunakan untuk mengeksploitasi daging binatang oleh manusia. Berikut ini adalah hasil analisis transformasi kultural terhadap sisa rangka fauna yang terpreservasi di situs Liangan:

Tabel 7. Jejak Transformasi Budaya (C-Transform) pada Tulang Fauna

\begin{tabular}{lrr}
\hline \multicolumn{1}{c}{ C-TRANSFORM } & JUMLAH & \multicolumn{1}{c}{$\%$} \\
\hline Chopping Mark & 18 & 24.66 \\
Terbakar & 1 & 1.37 \\
Matrik tanah & 13 & 17.81 \\
bercampur arang & & \\
Fragmentaris & 41 & 56.16 \\
TOTAL & $\mathbf{7 3}$ & $\mathbf{1 0 0}$ \\
\hline
\end{tabular}

Sumber: Tim Penelitian, 2016 dengan modifikasi

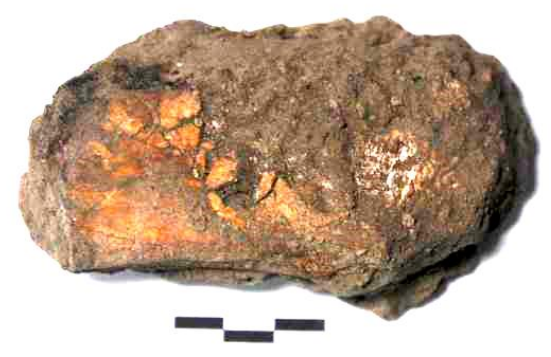

Gambar 3. Salah satu Tulang Panjang yang terpangkas kedua ujungnya

(Sumber: Balai Arkeologi D.I. Yogyakarta, 2016)

Berdasarkan pada hasil analisis tafonomi tersebut dapat diketahui bahwa sebagian besar tulang fauna di situs Liangan kondisinya sangat fragmentaris. Hal ini mungkin disebabkan oleh kondisi lingkungan situs tersebut yang kurang mendukung preservasi tulang belulang. Kondisi yang sama juga diketahui melalui analisis rangka manusia dari situs ini yang pernah dilakukan oleh Noerwidi (2014). Kondisi lingkungan di lereng gunung Sindoro yang tropis membuat lingkungan sekitar situs Liangan hampir selalu basah. Kondisi ini tidak menguntungkan bagi proses preservasi tulang fauna maupun rangka manusia.

Diketahui pula berdasarkan hasil pengamatan terhadap kondisi morfologi permukaan tulang-tulang fauna dari situs Liangan, terdapat banyak tulang dengan matrik tanah yang bercampur dengan arang. Selain itu, ada juga yang memiliki chopping mark (jejak pangkas), dengan potongan tulang sangat fragmentaris. Banyaknya tulang fauna yang terpotong mengindikasikan bahwa aktivitas eksploitasi fauna oleh manusia sangat intensif. Temuan tulang fauna dilokasi dengan matrik tanah bercampur arang, mengindikasikan adanya aktivitas memasak daging binatang. Sejauh ini hanya 
ditemukan satu spesimen tulang yang gosong terbakar, sehingga diperkirakan bahwa daging-daging tersebut tidak dimasak dengan cara dibakar langsung pada api.

\section{Determinasi Taksonomi}

Identifikasi jenis fauna dilakukan secara kualitatif terhadap karakter morfologi (aspek bentuk) yang masih terpreservasi pada temuan yang bersangkutan. Identifikasi anatomi tersisa dilakukan dengan cara perbandingan anatomi dengan menggunakan rujukan dari Barone (1976), Pales dan Gracia (1981), Schmidt (1972), serta Hilson (2005). Berikut ini adalah jenis fauna yang ditemukan di situs Liangan:

Tabel 8.Determinasi Kelompok

Fauna yang Ditemukan

\begin{tabular}{|c|c|c|}
\hline FAUNA & JUMLAH & $\%$ \\
\hline Bovidae & 63 & 86.30 \\
\hline Canidae & 1 & 1.37 \\
\hline Indet & 9 & 12.33 \\
\hline TOTAL & 73 & 100 \\
\hline $\begin{array}{l}\text { Sumber: Tim } \\
\text { modifikasi }\end{array}$ & an, 2016 & \\
\hline
\end{tabular}

Identifikasi jenis fauna yang ditemukan dari situs Liangan, sebagian besar didasarkan pada gigi-geligi dan fragmen tulang panjang. Berdasarkan pada hasil analisis tersebut dapat diketahui bahwa mayoritas fauna di situs tersebut berasal dari keluarga Bovidae (Sapi-Kerbau), sedangkan satu spesimen diidentifikasi milik keluarga Canidae (Anjing). Fauna Bovidae kemungkinan memang dipilih oleh manusia untuk dimanfaatkan, baik tenaga maupun dagingnya. Beberapa fragmen gigigeligi yang cukup utuh kondisi preservasinya mengindikasikan bahwa famili Bovidae di situs Liangan berasal dari kelompok
Bubalus sp. (kerbau). Kemudian, satu temuan fauna Canidae kemungkinan tidak berhubungan dengan aspek konsumsi, atau dalam hal ini untuk dimakan, karena tulang fauna tersebut ditemukan di permukaan jalan Halaman III Candi melalui kegiatan survei.

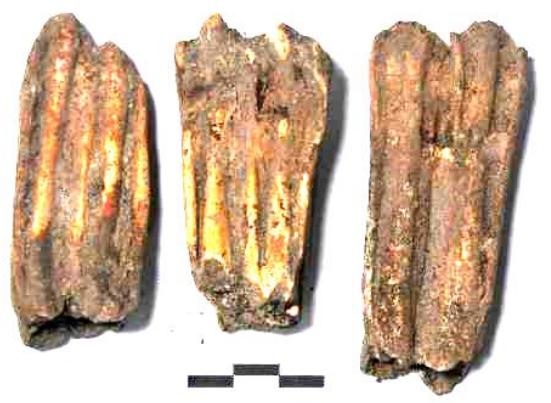

Gambar 4. Temuan Gigi Bovidae (Sumber: Balai Arkeologi D.I. Yogyakarta, 2016)

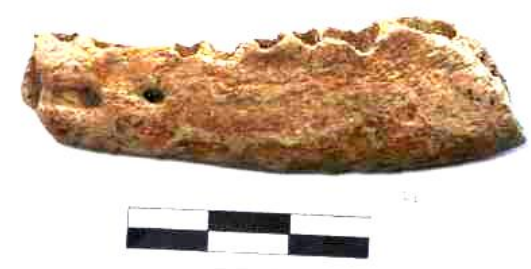

Gambar 5. Temuan Rahang Canidae (Sumber: Balai Arkeologi D.I. Yogyakarta, 2016)

\section{Estimasi Usia}

Penentuan usia hewan bertujuan untuk memperkirakan usia kematian mereka. Hal ini bisa dilakukan dengan mengamati tahap erupsi dan atrisi gigi, serta fusi tulang-tulang panjang. Untuk memperkirakan usia kematian hewan, dalam penelitian ini digunakan acuan Forsten dan Moigne (1998) tentang tingkat erupsi dan tahapan penggunaan gigi-geligi. Berdasarkan pada kedua variabel tersebut maka berikut ini dapat diketahui kelompok usia fauna yang ditemukan di situs Liangan, yaitu:

Berdasarkan penentuan usia hewan terhadap 16 spesimen yang 
terkonservasi dengan baik sehingga mampu untuk dianalisis, maka dapat diketahui bahwa mayoritas sebanyak 9 spesimen atau $56.25 \%$ berumur muda. Kemudian yang lainnya berumur dewasa dan atau tidak dapat diidentifikasi karena kondisi preservasinya yang fragmentaris. Hal ini mengindikasikan bahwa terdapat pemilihan kelompok usia pada hewan yang dikonsumsi oleh masyarakat penghuni situs Liangan. Pemilihan hewan muda untuk dikonsumsi merupakan hal yang sangat wajar, mengingat daging dari kelompok usia tersebut masih mudah untuk diolah dan lebih lezat dari pada hewan yang telah berumur.

Tabel 9. Estimasi Usia Fauna

Bovidae berdasarkan Gigi-geligi

\begin{tabular}{|c|c|c|}
\hline USIA & JUMLAH & $\%$ \\
\hline Sub-Adult & 9 & 56.25 \\
\hline Adult & 3 & 18.75 \\
\hline Indet & 4 & 25.00 \\
\hline TOTAL & 16 & 100 \\
\hline $\begin{array}{l}\text { Sumber: Tim } \\
\text { modifikasi }\end{array}$ & tian, 2016 & \\
\hline
\end{tabular}

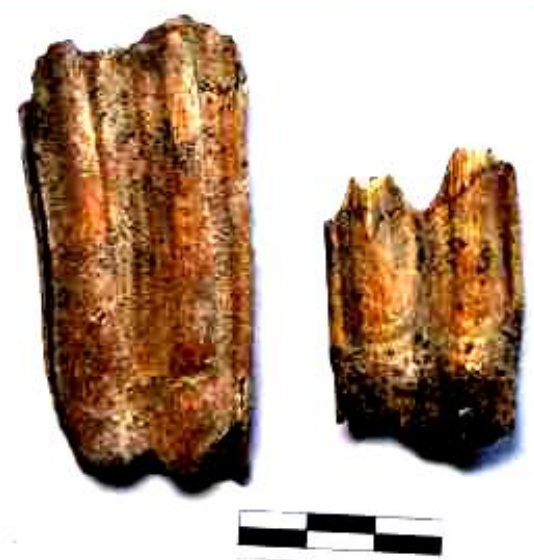

Gambar 6. Gigi Individu berusia Muda dan Dewasa (Sumber: Balai Arkeologi D.I. Yogyakarta, 2016)

\section{Pola Diet}

Untuk merekonstruksi pola diet fauna Bovidae yang ditemukan, maka dilakukan analisis mesowear. Analisis ini digunakan untuk mengetahui jejak pakai pada gigi yang didasarkan pada bentuk pertumbuhan relatif. $\mathrm{Hal}$ ini berdasarkan pada asumsi bahwa kondisi fisik bahan makanan direfleksikan pada besarnya derajat atrisi dan abrasi pada permukaan sisi occlusal gigi-geligi (Fortelius dan Solounias, 2000). Atrisi gigi adalah keausan gigi yang disebabkan oleh gesekan antara gigi rahang atas dan rahang bawah, sedangkan abrasi gigi adalah salah satu jenis keausan pada enamel yang diakibatkan selama aktivitas mengunyah bahan makanan yang banyak mengandung silika (Kaiser dkk, 2003: 67).

Analisis ini hanya dilakukan pada temuan gigi-geligi Bubalus $s p$ yang ditemukan di situs Liangan berdasarkan referensi dari studi serupa yang juga pernah dilakukan oleh Fortelius dan Solounias (2000) serta Kaiser et al, (2003). Dengan mengetahui jenis makanan yang dikonsumsi oleh hewan tersebut, maka secara tidak langsung dapat diketahui kondisi lingkungan di sekitar situs Liangan. Selain itu, dapat juga diidentifikasi kemungkinan intervensi kultural yang dilakukan oleh manusia terhadap pola konsumsi makanan yang dimakan oleh fauna Bovidae dari situs Liangan. Berikut adalah analisis bentuk (morfologi) occlusal dari gigi-geligi fauna yang ditemukan di situs Liangan.

Tabel 10.Bentuk Occlusal Gigi-geligi Fauna Bovidae

\begin{tabular}{lrr}
\hline \multicolumn{1}{c}{ OCCLUSAL } & JUMLAH & \multicolumn{1}{c}{$\%$} \\
\hline Runcing-Tinggi & 12 & 75.00 \\
Datar-Rendah & 3 & 18.75 \\
Runcing-Tumpul & 1 & 6.25 \\
TOTAL & $\mathbf{1 6}$ & $\mathbf{1 0 0}$ \\
\hline $\begin{array}{l}\text { Sumber: Tim Penelitian, } \\
\text { modifikasi }\end{array}$ & 2016 & dengan
\end{tabular}


Berdasarkan hasil analisis tersebut di atas, dapat diketahui bahwa sebagian besar (75\%) fauna Bubalus sp. di situs Liangan memiliki bentuk occlusal gigi yang pendek dan runcing. Pada family Bovidae, bentuk occlusal gigi yang runcing dengan relief occlusal yang tinggi biasanya dimiliki oleh jenis hewan yang makan daun (browser), sedangkan bentuk occlusal gigi yang datar dengan relief occlusal yang rendah biasanya dimiliki oleh jenis hewan yang makan rumput (grazer) (Kaiser et al, 2013: 37). Hal ini ada kaitannya dengan kandungan mineral silika dalam daun yang lebih rendah daripada dalam rumput, sehingga jejak pakai atau abrasi yang terekam pada sisi occlusal gigi nampak tidak intensif. Korelasi antara variabel mesowear dengan rekonstruksi paleodiet pernah diuji oleh Louys et al., (2012). Hasilnya, terdapat korelasi yang kuat antara bentuk occlusal dengan jenis makanan pada Bovidae.
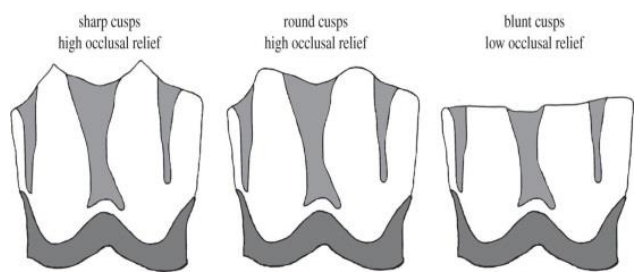

Gambar 7. Tipikal bentuk occlusal gigi Bovidae pemakan daun/browser (kiri), campuran/mix feeder (tengah), dan rumput/grazer (kanan)

(Sumber: Louys et al., 2012: 4442)

Oleh karena itu, maka dapat diketahui bahwa Bubalus sp situs Liangan lebih banyak mengonsumsi daun dari pada rumput. Hal yang menarik adalah bahwa Bubalus $s p$ secara natural pemakan rumput sejati, namun di situs Liangan mereka menjadi pemakan daun. Berdasarkan data occlusal gigi ini maka diperkirakan bahwa perubahan pola diet hewan yang bersifat artifisial tersebut disebabkan oleh aktivitas domestikasi fauna Bubalus $s p$ oleh masyarakat penduduk Liangan pada masa lampau.

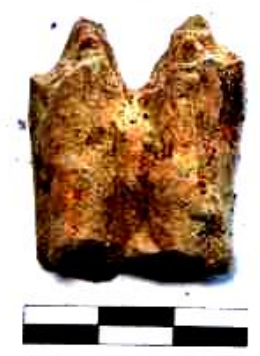

Gambar 8. Tipikal gigi Bovidae pemakan daun dengan bentuk occlusal runcing dan relief Occlusal yang tinggi

(Sumber: Balai Arkeologi D.I. Yogyakarta, 2016)

\section{KESIMPULAN}

Studi arkeozoologi dalam penelitian ini berhasil mengungkap beberapa aspek biologis fauna, dan hubungannya dengan aspek kultural manusia. Berdasarkan hasil analisis yang telah dilakukan tersebut dapat diketahui bahwa hampir keseluruhan temuan tulang dan gigi fauna di situs Liangan berasal dari jenis Kerbau (Bubalus sp). Kondisi preservasi dan tafonomi tulang kerbau ini mengindikasikan adanya eksploitasi fauna tersebut oleh masyarakat penghuni situs Liangan pada masa lampau.

Kondisi lingkungan dataran tinggi Gunung Sindoro yang basah dan lebat, tidak banyak menyediakan padang rumput sebagai habitat alami Bubalus $s p$ (kerbau). Kondisi ini mendorong manusia untuk melakukan domestikasi intensif terhadap fauna tersebut. Berdasarkan studi mesowear berdasarkan jejak pakai yang didasarkan pada bentuk pertumbuhan relatif pada gigi geligi 
dapat diketahui bahwa kerbau di situs Liangan lebih banyak mengkonsumsi daun (browser) yang kemungkinan besar disediakan oleh manusia, daripada jenis makanan lainnya.

Jenis-jenis eksploitasi kerbau untuk dikonsumsi oleh masyarakat pada masa Jawa Kuna belum dapat diketahui secara lebih mendalam dalam studi ini. Diharapkan pada masa mendatang perlu dilakukan studi lebih lanjut terhadap berbagai data historis seperti yang terdapat dalam prasasti dan relief candi. Kajian tersebut diharapkan mempu menggambarkan teknik pengolahan dan jenis makanan yang dihasilkan dari daging kerbau.

\section{SARAN/REKOMENDASI}

Analisis lebih mendalam mengenai sisa fauna dari situs Liangan masih perlu dilakukan, seperti analisis microwear terhadap jejak pakai berupa pola goresan pada bagian occlusal gigi-geligi untuk mengetahui campur tangan manusia yang lebih spesifik terhadap pola diet fauna dan pola eksploitasi fauna yang didomestikasi. Selain itu juga perlu dilakukan sintesis antara temuan sisa fauna dengan sisa flora -seperti misalnya pollen, phytolith dan starch- guna mendapatkan gambaran kondisi lingkungan masa lampau di Situs Liangan yang lebih lengkap.

Informasi-informasi saintifik
yang telah didapatkan melalui
berbagai macam analisis dari sudut
pandang keilmuan yang berbeda di
situs Liangan, pada masa yang akan
datang diharapkan dapat disajikan
dalam bentuk yang lebih populer
kepada masyarakat luas. Informasi
yang lebih populer tersebut misalnya
dapat berupa mengenai relasi antara
manusia dan fauna Bubalus sp
(Kerbau) seperti yang berhasil
diungkap dalam penelitian ini.

\section{UCAPAN TERIMA KASIH}

Terimakasih kepada Drs. Sugeng Riyanto, M.Hum, selaku Ketua Tim penelitian Situs Mataram Kuna, Liangan yang telah mengizinkan penulis untuk menganalisis dan mempublikasikan hasil penelitian ini. Terimakasih juga penulis sampaikan kepada rekanrekan di kelompok kerja penanganan temuan dan dokumentasi, Balai Arkeologi D.I. Yogyakarta yang telah membantu dalam melaksanakan penelitian ini. Tidak lupa, penulis mengucapkan terimakasih sebesarbesarnya pada Editor dan Mitra Bestari atas koreksi dan masukannya sehingga naskah ini dapat terbit dengan baik. 


\section{DAFTAR PUSTAKA}

Barone, R. 1976. Anatomie compare des mammifères domestiques, Tome I: Ostéologie (2 fascicules), Paris : Vigot Frères.

Binford, L R. 1981. Bones: Ancient Men and Modern Myths. Academic Press, New York.

Blondel, C., Merceron, G., Andossa, L., Taisso, M. H., Vignaud, P., dan Brunet, M. 2010. "Dental mesowear analysis of the late Miocene Bovidae from Toros-Menalla (Chad) and early hominid habitats in Central Africa".Palaeogeography, Palaeoclimatology, Palaeoecology, 292(1),hlm. 184-191.

Blumenschine, $R$ J. 1986. "Carcass consumption sequences and the archaeological distinction of scavenging and hunting".Journal of Human Evolution, vol. 15, hlm. 639-59.

Castillo, C C. 2014. "The Rice Remains from Temanggung First evidence of tropical japonica in Indonesia”, Liangan: Mozaik Peradaban Mataram Kuno di Lereng Sindoro, Yogyakarta: Balai Arkeologi Yogyakarta, hlm. 267-278.

Eriawati, Y. 2014. "Keramik Cina Dinasti Tang Abad IX Masehi dari Situs Liangan,Temanggung, Jawa Tengah", Liangan: Mozaik Peradaban Mataram Kuno di Lereng Sindoro, Yogyakarta: Balai Arkeologi Yogyakarta, hlm. 215-266.

Forsten, A. dan Moigne, A-M.1998. "The horse from the Middle Pleistocene of Orgnac 3 (Ardèche, France)". Quaternaire, Paris, Vol. 9, No. 4, hlm. 31523.

Fortelius, M., dan Solounias, N. 2009. Functional characterization of ungulate molars using the abrasion-attrition wear gradient: a new method for reconstructing paleodiets.

Gaudzinski-Windheuser, S., dan Kindler, L. 2012. "Research perspectives for the study of Neandertal subsistence strategies based on the analysis of archaeozoological assemblages." Quaternary International 247: hlm. 59-68.

Hilson, S. 2005. Teeth.Cambridge University Press. 
Klein, R.G. dan Cruz-Uribe, K. 1984. The analysis of animal bones from archaeological sites. Chicago: The University of Chicago press, $226 \mathrm{hlm}$.

Kaiser, T. M., dan Fortelius, M. 2003. "Differential mesowear in occluding upper and lower molars: opening mesowear analysis for lower molars and premolars in hypsodont horses". Journal of Morphology, 258(1),hlm. 67-83.

Kaiser, T. M., Müller, D. W., Fortelius, M., Schulz, E., Codron, D., dan Clauss, M. 2013. "Hypsodonty and tooth facet development in relation to diet and habitat in herbivorous ungulates: implications for understanding tooth wear", Mammal Review, 43(1),hlm. 34-46.

Lyman, R. L. 1984. "Bone density and differential survivorship of fossil classes".Journal Anthrpological Archaeology, vol. 3, hlm. 259-299.

1994. "Quantitative units and terminology in zooarchaeology".American Antiquity, vol. 59, no. 1, hlm. 36-71.

Louys, J., Ditchfield, P., Meloro,C., Elton,S., dan Bishop, L.C. 2012."Stable isotopes provide independent support for the use of mesowear variables for inferring diets in African antelopes",Proceedings of the Royal Society of London B: Biological Sciences 279, no. 1746, hlm. 4441-4446.

Marean, C.W., dan Spencer,L.M.1991. "Impact of carnivore ravaging on zooarchaeological measures of element abundance". American Antiquity, vol. 56, no; 4, hlm. 645-658.

Mochtar, A S. 2014. "Wanua i Rukam, Nama Asli Situs Liangan? Kajian terhadap Prasasti Rukam 907 M sebagai data Pendukung Penelitian Situs Liangan", Liangan: Mozaik Peradaban Mataram Kuno di Lereng Sindoro, Yogyakarta: Balai Arkeologi Yogyakarta, hlm. 149-164.

Nastiti, T S., Dewi D W., dan Kartakusuma R.1982. Tiga Prasasti dari Masa Balitung. Jakarta: Pusat Penelitian Arkeologi Nasional.

Nurnusanto, I. 2014. "Catatan Geologis Situs Candi Liangan”, Liangan: Mozaik Peradaban Mataram Kuno di Lereng Sindoro, Yogyakarta: Balai Arkeologi Yogyakarta, hlm. 117-122.

Noerwidi, S. 2016. "Aspek Biokultural Sisa Rangka Manusia dari Situs Liangan, Temanggung, Jawa Tengah." Berkala Arkeologi Vol 36 No.1 Mei, Yogyakarta: Balai Arkeologi D.I. Yogyakarta, hlm.83-98. 
Pales, L. dan Gracia, M.A. 1981. Atlas ostéologique pour servir à l'identification des mammiferes du Quaternaire:Herbivores, II- tête, rachis, ceintures scapulaires et pelviennes, membres. Eds. du CNRS, Paris, $177 \mathrm{hlm}$.

Rangkuti, N. dan Tjahjono, B D. 2000. "Laporan Peninjauan Situs Liyangan, Temanggung, Laporan Penelitian Arkeologi, Yogyakarta: Balai Arkeologi Yogyakarta.

Riyanto, S. 2014a. "Mozaik Peradaban Liangan Kuno", Liangan: Mozaik Peradaban Mataram Kuno di Lereng Sindoro, Yogyakarta: Balai Arkeologi Yogyakarta, hlm. 1-30.

2014b. "Menggali Peradaban Mataram Kuno di Liangan tahap Demi Tahap", Liangan: Mozaik Peradaban Mataram Kuno di Lereng Sindoro, Yogyakarta: Balai Arkeologi Yogyakarta, hlm. 31-116.

Schmidt, E. 1972. Atlas of Animal Bones. Amsterdam: Elsevier.

Tanaka, K. 2014. "Report of Dna Analysis for Rice Remainsat Javanese Settlement Site, Indonesia", Liangan: Mozaik Peradaban Mataram Kuno di Lereng Sindoro, Yogyakarta: Balai Arkeologi Yogyakarta, hlm. 279-292.

Tim Penelitian, 2016. "Permukiman Masa Mataram Kuno Situs Liangan, Temanggung, Jawa Tengah",Laporan Penelitian Arkeologi, Yogyakarta: Balai Arkeologi D.I. Yogyakarta.

Yohe II, Robert M. 2006. Archaeology: The Science of the Human Past. Pearson. hlm. 248-264. 
